\title{
Model Pembelajaran PBL Dipadu Strategi NHT Untuk Memotivasi dan Meningkatkan Hasil Belajar Peserta Didik
}

\author{
Hardianti Hardianti \\ Pendidikan Kimia, Universitas Riau \\ Email: hardianti213@gmail.com \\ Jimmi Copriady \\ Pendidikan Kimia, Universitas Riau \\ Email: jimmi.c@lecturer.unri.ac.id \\ Sri Haryati \\ Pendidikan Kimia, Universitas Riau \\ Email: srifkipunri@yahoo.co.id
}

(Diterima: 11-Desember-2019; direvisi: 10-Januari-2020; dipublikasikan: 11-Maret-2020)

\begin{abstract}
Abstrak: Tujuan penelitian ini ialah untuk meningkatkan motivasi belajar dan hasil belajar peserta didik dengan menerapkan model pembelajaran PBL dipadu strategi NHT untuk pokok bahasan stoikiometri di MAN 1 Pekanbaru. Populasi yang terlibat pada penelitian ini ialah semua peserta didik kelas X MIA yang terdiri dari empat kelas. Analisis data penelitian digunakan uji normalitas dan uji homogenitas. Uji normalitas dilakukan dengan uji Liliefors dan uji homogenitas menggunakan uji kesamaan varian dan uji kesamaan rata-rata. Pengambilan dan penentuan sampel menggunakan metode Cluster random sampling diperoleh dua kelas yaitu kelas X MIA 1 untuk kelas kontrol dan kelas X MIA 4 untuk kelas eksperimen. Hasil pengujian hipotesis dengan uji-t membuktikan jika terdapat perbedaan signifikan antara kelas kontrol dan kelas eksperimen motivasi belajar maupun hasil belajar peserta didik. Dimana untuk motivasi belajar dan hasil belajar peserta didik kelas eksperimen lebih tinggi dibanding peserta didik pada kelas kontrol. Penentuan hubungan motivasi terhadap hasil belajar peserta didik dilakukan dengan menggunakan uji korelasi person yang membuktikan bahwa terdapat hubungan motivasi terhadap hasil belajar peserta didik pada kelas yang menerapkan model pembelajaran PBL dipadu strategi NHT pada pokok bahasan stoikiometri di MAN 1 Pekanbaru dengan kategori korelasi positif kuat.
\end{abstract}

Kata kunci: Model Pembelajaran PBL Dipadu Strategi NHT; Motivasi Belajar; Hasil Belajar; Stoikiometri.

Abstract: This study aims to increase learning motivation and results student learning through the application of the PBL learning model combined with the NHT strategy on the subject of stoichiometry at MAN 1 Pekanbaru. The population in this study is all students of class X MIA, amounting to four classes. Normality test use Liliefors test which aims to see whether the data used have a normal distribution and homogeneity test using the variance similarity test and test average similarity which aims to see whether the sample used is already homogeneous. Sampling is done by the cluster random sampling method obtained by two classes namely class X MIA 1 as a control class and class X MIA 4 as an experimental class. The results of testing the hypothesis using the t-test showed that there are significant differences between the control class and the experimental class on learning motivation and learning outcomes. Where is learning motivation and results learning experimental class 
students higher than students in the class control. Determination of the relationship of learning motivation to student learning outcomes done with a person correlation test that shows the existence of a relationship between learning motivation towards learning outcomes of students in the class applied PBL learning models combined NHT strategies on the subject of stoichiometry at MAN 1 Pekanbaru with a strong positive correlation category.

Keywords: PBL Learning Models Combined With NHT Strategies; Learning Motivation; Learning Outcomes; Stoichiometric.

\section{PENDAHULUAN}

Pendidikan ialah aspek penting dalam kehidupan manusia. Keberhasilan dunia pendidikan dapat dilihat dari kualitas pendidikan, oleh karena itu perlu dilakukannya perbaikan, perubahan dan pembaharuan dalam aspek pendidikan agar didapat pendidikan yang berkualitas dan bermutu. Masalah yang sering muncul dibidang pendidikan ialah proses pembelajaran yang pasif, salah satunya dikarenakan oleh belum siapnya peserta didik dalam menerima materi pembelajaran yang akan disampaikan sehingga proses belajar mengajar dikelas kurang berjalan dengan maksimal. Peserta didik sebagai pembelajar seharusnya dapat lebih aktif ketika proses belajar mengajar berlangsung. Keaktifan peserta didik ini dapat dinilai dari tingkah lakunya ketika mengikuti proses pembelajaran seperti saat peserta didik bertanya, menjawab pertanyaan, memberi tanggapan dan lainnya.

Kimia merupakan satu dari banyaknya mata pelajaran yang ada di SMA/sederajat terkhususnya untuk jurusan MIA. Pelajaran kimia sering dianggap pelajaran yang sukar untuk dipahami oleh peserta didik sehingga peserta didik tidak tertarik terhadap pelajaran kimia. Dan juga peserta didik merasa sulit dalam memahami konsep kimia dari pada konsep pelajaran lain karena karakteristik ilmu kimia itu sendiri bersifat abstrak (Rusman, 2012). Dalam mempelajari kimia peserta didik juga dituntut untuk dapat memahami konsep dan keterkaitan antar konsepnya. Pemahaman peserta didik dalam menguasai konsep materi pelajaran akan berdampak pada hasil belajar yang didapatkan peserta didik dimana jika konsep yang dipahami peserta didik sedikit atau rendah maka hasil belajar peserta didik juga ikut rendah. Pemahaman konsep peserta didik yang rendah ini dapat disebabkan karena model pembelajraan yang diaplikasikan guru pada saat proses belajar mengajar kurang menarik. Guru seharusnya dapat memberikan pembelajaran yang menarik agar peserta didik mampu berkomunikasi pada saat proses belajar berlangsung baik dengan guru maupun dengan teman sebayanya dan peserta didik dapat saling bertukar informasi. Hal ini mengharuskan guru untuk dapat menggunakan model pembelajaran dan strategi pembalajaran yang dapat menimbulkan motivasi belajar peserta didik.

Motivasi memiliki pengaruh terhadap keberhasilan yang diraih peserta didik dalam proses pembelajaran. Ini dikarenakan saat proses pembelajaran berlangsung motivasi memiliki peranan penting yang bisa mendorong peserta didik untuk melakukan kegiatan belajar agar terjadi peralihan tingkah laku untuk meraih suatu tujuan yang berupa hasil belajar yang tinggi. Motivasi belajar ialah suatu keadaan dalam diri yang dapat mendorong dan mengarahkan perilaku pada tujuan yang akan dicapai dalam mengikuti pendidikan (Nila Puspita Sari, 2017). Peserta didik akan terdorong untuk dapat menguasai bahan pelajaran dengan baik, tidak hanya sekedar lulus walau dengan nilai yang baik sekalipun. Yokhabet, dkk (2012) menyatakan peningkatan motivasi belajar sejalan dengan kenaikan hasil belajar peserta didik dan motivasi belajar telah mendorong tercapainya tujuan pembelajaran yang dituju.

Penelitian tentang memotivasi dan meningkatkan hasil belajar peserta didik 
melalui penerapan model PBL dipadu strategi NHT ini dilakukan untuk kelas X MIA MAN 1 Pekanbaru. Materi yang dipelajari ialah materi stoikiometri. Berdasarkan hasil observasi awal mengenai hasil belajar pada pokok bahasan stoikiometri masih rendah dilihat dari nilai rata-rata belum tercapainya KKM yang telah ditentukan sekolah yaitu 75. Ini dikarenakan peserta didik masih kesulitan dalam menguasai pokok bahasan yang disampaikan dan sulit dalam memahami soal-soal yang berkesinambungan dengan materi stoikiometri yang diberikan guru.

Model pembelajaran yang bercirikan konstruktivisme, terfokus pada peserta didik dan berfokus pada pembelajaran ialah model pembelajaran Problem Based Learning (PBL). Menurut teori Ibrahim (2002) PBL ialah model yang memfokuskan pada masalah sebagai titik mula dalam mengakuisisi pengetahuan baru. Sedangkan menurut Warsono (2012) pembelajaran berdasarkan masalah ialah model pembelajaran konstruktivisme dan dapat membantu keterlibatan peserta didik dalam belajar serta peserta didik terlibat langsung dalam pemecahan masalah yang konstektual. Sehingga peserta didik akan aktif, kreatif dan inovatif yang sejalan dengan tujuan dari kurikulum yang ada.

Penerapan model pembelajran PBL dalam proses belajar diharapkan akan mendorong peserta didik untuk lebih memiliki inisiatif pada saat belajar secara mandiri. Salah satu strategi belajar yang dapat mendukung pelaksanaan model pembelajaran PBL ini adalah strategi NHT. Dalam strategi NHT peserta didik akan saling ketergantungan positif satu sama lain, memiliki tanggung jawab perseorangan, dan terjadinya komunikasi antar anggota kelompok. Pada strategi NHT, peserta didik akan menempati posisi yang dominan dalam proses belajar mengajar. Kerja sama dalam kelompok ditandai dengan adanya penomoran sehingga peserta didik akan terdorong untuk berusaha memahami dan mampu menyelesaikan permasalahan yang sedang mereka hadapi sehingga setiap anggota kelompok memiliki tanggung jawab atas nomornya masing-masing karena setiap individu dalam kelompok akan mempunyai kesempatan yang sama untuk mewakili kelompoknya dalam mempersentasikan hasil diskusi kelompoknya.

PBL dipadu strategi NHT telah dilakukan pada penelitian sebelumnya, sehingga dapat diambil untuk bahan dalam mempertimbangkan penelitian yang dilakukan. Anyta Kusumaningtias membuktikan terdapat pengaruh yang signifikan pada model pembelajaran Problem Based Learning dipadu strategi Numbered Heads Together terhadap kemampuan metakognitif, berpikir kritis dan kognitif biolohi siswa kelas XI IPA SMAN 5 Malang. Selain itu Nila Puspita Sari memperoleh hasil penelitiannya terdapat pengaruh penggunaan model pembelajaran Problem Based Learning (PBL) dipadu strategi Numbered Heads Together (NHT) terhadap keterampilan metakognitif dan kemampuan berfikir kritis pada materi lingkungan hidup siswa SMA.

Berdasarkan pada penelitian terdahulu tentang model pembelajaran PBL dipadu strategi NHT dengan penelitian yang dilakukan peneliti pada saat ini terdapat perbedaan yaitu pada rancangan penelitian, variabel, lokasi, subjek dan pokok bahasan pelajaran yang diteliti. Tujuan penelitian ini untuk mengetahui apakah model PBL dipadu strategi NHT dapat meningkatkan motivasi dan hasil belajar peserta didik kelas X MIA MAN 1 Pekanbaru. Sesuai dengan pemaparan diatas peneliti tertarik untuk melakukan penelitian dengan judul "Model Pembelajaran PBL dipadu strategi NHT untuk Memotivasi dan Meningkatkan Hasil Belajar Peserta Didik pada Pokok Bahasan Stoikiometri MAN 1 Pekanbaru".

\section{METODE}

Penelitian ini merupakan penelitian quasi eksperimen dengan rancangan Nonequivalent Control Grup Design. Sampel yang digunakan dalam penelitian ini 
sebanyak 67 peserta didik dimana 33 peserta didik kelas eksperimen yang diberikan perlakuan model pembelajaran PBL dipadu strategi NHT dan 34 peserta didik kelas kontrol yang tanpa diberi perlakuan model pembelajaran PBL dipadu strategi NHT. Penelitian ini dilakukan di MAN 1 Pekanbaru dari februari sampai mei 2019.

Pengumpulan data menggunakan data tes hasil belajar peserta didik dan data angket motivasi peserta didik. Tes hasil belajar peserta didik merupakan soal-soal pilihan ganda dengan jumlah 25 item soal dari 30 item soal yang sebelumnya telah di uji validitas dan reliabilitasnya. Tes hasil belajar diberikan dua kali yaitu pada saat sebelum (pretest) dan sesudah (posttest). Angket motivasi belajar peserta didik merupakan pertanyaan yang diberikan kepada peserta didik untuk dijawab sesuai dengan keadaan yang sebenarnya yang terdiri dari 20 item pertanyaan yang sebelumnya juga sudah diuji validitas dan reliabilitasnya. Angket motivasi belajar peserta didik diberikan diakhir pertemuan belajar.

Teknik analisis data yang digunakan dalam penelitian ini ialah analisis data instrumen yang digunakan (instrument motivasi belajar dan instrument hasil belajar) menggunakan uji validitas dan uji reliabilitas. Analisis data penelitian untuk menguji hipotesis menggunakan uji-t dan uji korelasi person. Sebelum dilakukan uji hipotesis terlebih dahulu dilakukan uji prasyarat analisis, dimana untuk uji normalitas digunakan uji Liliefors dan untuk uji homogenitas digunakan uji-F dan uji-t.

\section{HASIL DAN PEMBAHASAN}

Sebelum dilakukan analisis uji
hipotesis maka data hasil belajar dan motivasi belajar harus memenuhi prasyarat. Dimana uji prasyarat yang harus dilakukan agar pengujian hipotesis dapat dilaksanakan ialah uji normalitas dan uji homogenitas.

Uji normalitas data yang digunakan ialah uji Liliefors, bertujuan untuk melihat apakah data yang digunakan dalam penelitian berdistribusi normal atau tidak. Uji normalitas data dianalisis dari nilai ulangan sebelum materi stoikiometri (redoks) dan data nilai pretest-posttest peserta didik. Berdasarkan hasil pengujian untuk data nilai ulangan materi sebelum stoikiometri (redoks) dan nilai pretestposttest peserta didik didapatkan hasil pengujian yaitu nilai $\mathrm{L}_{\text {maks }}<\mathrm{L}_{\text {tabel }}$ yang menunjukkan bahwa data penelitian yang digunakan telah terdistribusi normal.

Uji homogenitas dilakukan untuk mengetahui apakah data penelitian yang digunakan homogen atau tidak. Uji homogenitas dilakukan apabila data yang penelitian telah berdistribusi normal. Uji homogenitas menggunakan uji kesamaan varian (uji-F) dan uji kesamaan rata-rata (uji-t). Setelah dilakukan uji homogenitas didapatkan hasil bahwa kedua kelas yang digunakan telah homogen. Selanjutnya dipilih secara acak dan didapatkan kelas X MIA 1 sebagai kelas kontrol dan kelas $\mathrm{X}$ MIA 4 sebagai kelas eksperimen.

Data penelitian yang sudah terdistribusi normal dan mempunyai kemampun awal yang homogen, selanjutnya dilakukan pengujian hipotesis. Pengujian Hipotesis peningkatan hasil belajar menggunakan uji-t pihak kanan dimana untuk kriteria pengujian ini ialah apabila $t_{\text {hitung }}>t_{\text {tabel }}$ maka hipotesis diterima. Hasil pengujian hipotesis penelitian dapat dilihat pada Tabel 1.

Tabel 1. Hasil Analisis Uji Hipotesis Peningkatan Hasil Belajar

\begin{tabular}{cccccccc}
\hline Kelompok & $\mathbf{N}$ & $\overline{\boldsymbol{x}}$ & $\mathbf{S}_{\text {gab }}$ & $\mathbf{t}_{\text {hitung }}$ & $\mathbf{t}_{\text {tabel }}$ & Keterangan & Kesimpulan \\
\hline $\begin{array}{c}\text { Eksperimen } \\
\text { Kontrol }\end{array}$ & 33 & $\begin{array}{c}61,6969 \\
60\end{array}$ & 2,6281 & 2,64 & \multirow{2}{*}{1,67} & $\mathrm{t}_{\text {hitung }}>\mathrm{t}_{\text {tabel }}$ & $\begin{array}{c}\text { Hipotesis } \\
\text { Diterima }\end{array}$ \\
\hline
\end{tabular}


Pada tabel 1 menunjukkan bahwa $\mathrm{t}_{\text {hitung }}=2,64$ dan $\mathrm{t}_{\text {tabel }}$ yang diperoleh dari $\mathrm{dk}=33=34-2=65$ adalah 1,67. Diperoleh $t_{\text {hitung }}>t_{\text {tabel }} \quad(2,64>1,67)$ maka hipotesis diterima. Sehingga model PBL dipadu strategi NHT dapat meningkatkan hasil belajar peserta didik pada pokok bahasan stoikiometri di MAN 1 Pekanbaru.

Kategori peningkatan hasil belajar peserta didik dapat diketahui dengan uj $\mathrm{N}$ gain dan diperoleh hasil pengujian yaitu
0,8016 untuk kelas eksperimen dan 0,7715 untuk kelas kontrol. Hal ini menunjukkan bahwa nilai $\mathrm{N}$-gain pada kelas eksperimen lebih tinggi dibandingkan dengan kelas kontrol.

Hipotesis perbedaan motivasi belajar peserta didik kelas eksperimen dan kelas kontrol dilakukan dengan menggunakan uji t dua pihak. Dimana hasil pengujian hipotesis perbedaan motivasi belajar dapat dilihat pada Tabel 2.

Tabel 2. Hasil Analisis Uji Hipotesis Perbedaan Motivasi Belajar

\begin{tabular}{cccccccc}
\hline Kelompok & $\mathbf{N}$ & $\overline{\boldsymbol{x}}$ & $\mathbf{S}^{\mathbf{2}}$ & $\mathbf{t}_{\text {hitung }}$ & $\mathbf{t}_{\text {tabel }}$ & Keterangan & Kesimpulan \\
\hline Eksperimen & 33 & 70,27 & 24,01 & \multirow{2}{*}{9,12} & \multirow{2}{*}{2,00} & \multirow{2}{*}{$\mathrm{t}_{\text {hitung }}>\mathrm{t}_{\text {tabel }}$} & Hipotesis \\
Kontrol & 34 & 61,11 & 9,98 & & & Diterima \\
\hline
\end{tabular}

Berdasarkan tabel 2 didapatkan nilai $t_{\text {hitung }}$ sebesar 9,12 yang dibandingkan dengan nilai $t_{\text {tabel, }}$, dimana nilai $t_{\text {tabel }}$ yang diperoleh dari $\mathrm{dk}=33+34-2=65 \quad(\alpha=5 \%)$ adalah 2,00 terlihat bahwa nilai $t_{\text {hitung }}>t_{\text {tabel }}$ $(9,12>2,00)$ sehingga hipotesis diterima. Jadi dapat disimpulkan bahwa terdapat perbedaan motivasi belajar yang signifikan antara kelas eksperimen yang menggunakan model pembelajaran PBL dipadu strategi NHT dengan kelas yang tidak menggunakan model pembelajaran PBL dipadu strategi NHT.

Hubungan motivasi belajar terhadap hasil belajar kelas eksperimen dan kelas kontrol dapat diketahui dengan menggunakan uji korelasi person. Dimana setelah dilakukan pengujian didapatkan hasil $\mathrm{r}_{\text {hitung }}$ untuk kelas eksperimen ialah 0,658 yang lebih besar dari $r_{\text {tabel }}$ yaitu 0,344 $(0,658>0,344)$ hal ini menunjukkan bahwa pada kelas eksperimen yang diterapkan model pembelajaran PBL dipadu strategi NHT terdapat hubungan yang positif kuat antara motivasi belajar terhadap hasil belajar. Sedangkan pada kelas kontrol

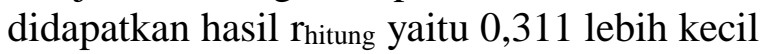
dari $r_{\text {tabel }}$ yaitu $0,339 \quad(0,311<0,339)$ yang menunjukkan bahwa pada kelas kontrol tidak terdapat hubungan anatara motivasi belajar terhadap hasil belajar peserta didik.
Motivasi belajar pada kelas eksperimen lebih tinggi dibandingkan motivasi belajar pada kelas kontrol hal ini disebabkan karena pada kelas ekperimen diterapkan model pembelajaran PBL dipadu strategi NHT yang dapat membuat peserta didik memiliki rasa tanggung jawab yang besar dalam kelompoknya untuk dapat lebih memahami konsep yang dipelajarinya agar dapat menjaga nama baik kelompoknya. Penerapan model pembelajaran PBL dipadu strategi NHT ini juga dapat meningkatkan semangat kerjasama peserta didik didalam kelompoknya. Hal ini sesuai dengan pendapat Sardiman (2010) yang menyatakan bahwa motivasi ialah kekuatan atau pendorong bagi seseoarang untuk mencapai tujuannya dimana seseorang akan berhasil dalam belajar, apabila pada dirinya sendiri memiliki keinginan untuk belajar yang ditandai dengan penumbuhan gairah untuk belajar, merasa senang dan semangat dalam belajar.

Penggunaan model pembelajaran PBL dipadu strategi NHT dapat meningkatkan hasil belajar peserta didik yang ditandai dengan meningkatnya aktivitas belajar peserta didik dalam proses belajar mengajar dan juga proses belajar mengajar akan lebih bermakna karena peserta didik dapat mengembangkan pengetahuannya dalam menyelesaikan 
masalah yang diberikan. Hal ini terjadi karena model pembelajaran PBL dipadu strategi NHT menuntut peserta didik untuk dapat memecahkan masalah sesuai dengan penguasaan materi yang mereka miliki. Jimmi Copriady (2014) mengatakan bahwa model PBL dikembangkan untuk membantu peserta didik mengembangakan kemampuan berfikir, pemecahan masalah keterampilan intelektual melalui pelibatan mereka sendiri dan menjadi pembelajara yang otonom dan mandiri.

Proses pembelajaran menggunakan model pembelajaran PBL dipadu strategi NHT diawali dengan mengelompokkan peserta didik dalam kelompok yang heterogen yang terdiri dari 5-6 orang dalam satu kelompok dimana peserta didik telah menggunakan nomor kepalanya masingmasing dalam kelompoknya. Didalam kelompok peserta didik akan berdiskusi dan saling kerja sama antar peserta didik yang dapat mengaktifkan interaksi antar peserta didik. Sesuai dengan pernyataan Slavin (2010) bahwa belajar kelompok atau berdiskusi dapat memberikan kesempatan terjadinya interaksi antar peserta didik dengan teman sebayanya. Sehingga peserta didik akan lebih mudah dalam memahami konsep yang sulit jika saling berdiskusi.

Tahapan model pembelajaran PBL dipadu strategi NHT dimulai dengan tahapan pertama yaitu tahap orientasi peserta didik terhadap masalah. Pengorientasian peserta didik pada masalah yang nyata dlaam kehidupan merupakan salah satu stimulus agar peserta didik mendapatkan lebih banyak kecakapan daripada pengetahuan yang dihafalnya sendiri. Tahap selanjutnya yaitu mengorganisasi peserta didik untuk belajar dimana pada tahap ini peserta didik telah duduk dalam kelompoknya dan guru akan memberikan LKPD kepada peserta didik dimana peserta didik diminta untuk membaca dan memahami petunjuk pengisian LKPD. Tahap selanjutnya yaitu membimbing penyelidikan individual maupun kelompok. Dimana pada tahap ini guru mendorong peserta didik untuk mengumpulkan informasi yang sesuai dan relevan serta jelas agar peserta didik dapat menyelesaikan masalah yang sedang diselidiki dalam LKPD. Sesuai dengan pernyataan pedoman umum pengembangan bahan ajar yang disusun oleh Depdiknas (2008) yang menyatakan bahwa LKPD merupakan kepanjangan dari lembar kegiatan peserta didik yang merupakan lembaran-lembaran berisi tugas yang harus dikerjakan peserta didik. LKPD juga merupakan panduan peserta didik yang digunakan untuk melakukan kegiatan penyelidikan atau pemecahan masalah (Trianto, 2012).

Tahap selanjtnya yaitu

mengembangkan dan menyajikan hasil karya, dimana pada tahap ini guru membantu peserta didik untuk menyelesaikan LKPD yang telah diberikan dan guru meminta peserta didik untuk menyajikan LKPD yang telah dibahas bersama kelompoknya didepan kelas. Pada tahap menyajikan hasil karya ini guru menggunakan strategi NHT dimana kelompok yang akan mempersentasikan hasil LKPD nya didepan kelas akan diacak nomor kepalanya dan guru akan mencabut undi salah sau nomor kepala peserta didik yang akan mewakili kelompoknya untuk mempersentasikan hasil diskusi kelompoknya. Guru berperan sebagai fasilitator, mengamati aktivitas peserta didik dan membantu peserta didik yang mengalami kesulitan. Anita Lie (2010) menyatakan bahwa selama kegiatan kelompok berlangsung guru bertindak sebagai fasilitator yang memonitor kegiatan tiap peserta didik dan memotivasi peserta didik untuk berinteraksi antar sesama teman sekelompoknya, maupun dengan guru dan guru akan membantu peserta didik apabila terdapat kesulitan. Tahap terakhir dari model pembelajaran PBL dipadu strategi NHT adalah tahap menganalisis dan mengevaluasi proses pemecahan masalah, dimana pada tahap ini guru membantu peserta didik untuk melakukan refleksi dan penarikan kesimpulan serta mengevaluasi peserta didik terhadap proses yang telah mereka pelajari. 


\section{SIMPULAN DAN SARAN}

Dari hasil analisis data dan uraian pembahasan maka dapat disimpulkan bahwa model pembelajaran PBL dipadu strategi NHT dapat memotivasi dan meningkatkan hasil belajar peserta didik pada pokok bahasan stoikiometri dan terdapat hubungan positif kuat antara motivasi belajar terhadap hasil belajar peserta didik yang diterapkan model pembelajaran PBL dipadu strategi NHT pada pokok bahasan stoikiometri di MAN 1 Pekanbaru.

\section{DAFTAR RUJUKAN}

Copriady, J. 2014. Penerapan SPBM yang Diintegrasikan dengan Program eXe Learning terhadap Motivasi Hasil Belajar Mahasiswa pada Mata Kuliah Kimia Dasar. Jurnal Pendidikan, (5), 95-105.

Depdiknas. 2008. Pengembangan Bahan Ajar. Direktorat Pembinaan Sekolah Menengah Atas Direktorat Jenderal Manajemen Pendidikan Dasar dan Menengah Departemen Pendidikan Nasional. Jakarta.

Ibrahim, M. 2002. Pengajaran Berdasarkan Masalah. Surabaya: UNESSA Press.

Lie, A. 2010. Cooperative Learning, Memperaktekkan Cooperative Learning di Ruang-ruang Kelas. Jakarta: Grasindo.

Robert E. Slavin. 2010. Cooperative Learning (Teori, Riset, dan Praktik). Nusa Media. Bandung.

Rusman. 2012. Model-Model Pembelajaran: Mengembangkan Profesionalisme Guru. Rajawali Pers. Jakarta.

Sardiman, A. M. 2010. Interaksi dan Motivasi Belajar Mengajar. Rajawali Pers. Jakarta.

Sari, N. P. 2017. Pengaruh Penerapan Model Pembelajaran Problem Based Learning Dipadu Numbered Heads Together terhadap Keterampilan Metakognitif dan Kemampuan Berpikir Kritis Geografi Siswa SMA. Jurnal pendidikan, 2(3), 440-447.
Trianto. 2012. Model-model Pembelajaran Inovatif Berorientasi

Konstruktivistik. Prestasi Pustaka. Jakarta.

Warsono dan Hariyanto. 2012. Pembelajaran Aktif. Remaja Rosdakarya. Bandung.

Yokhabet, S. S., \& Sunarno W. 2012. Pembelajaran Biologi Menggunakan Model Pembelajaran Berbasis Masalah dengan Keterampilan Proses Sains Untuk Meningkatkan Motivasi Belajar dan Hasil Belajar. Jurnal inkuiri, 1(3), 183-184. 